\title{
ELEMEN PENGAMBILAN KEPUTUSAN KEPERAWATAN YANG TEPAT SEBAGAI SALAH SATU TOLAK UKUR ASUHAN KEPERAWATAN
}

\author{
Kristina N Tampubolon \\ kristinatampubolon381@gmail.com
}

\begin{abstract}
ABSTRAK
Manajemen keperawatan merupakan suatu bentuk koordinasi dan integrasi sumbersumber keperawatan dengan menerapkan proses manajemen untuk mencapai tujuan dan obyektifitas asuhan keperawatan dan pelayanan keperawatan. Proses manajemen dibagi menjadi lima tahap yaitu perencanaan, pengorganisasian, kepersonaliaan, pengarahan dan pengendalian. Manajemen keperawatan memahami dan memfasilitasi pekerjaan perawat pelaksana serta mengelola kegiatan keperawatan. Keberhasilan pelayanan keperawatan sangat dipengaruhi oleh perawat dalam melaksanakan peran dan fungsinya. Manajemen keperawatan adalah proses kerja setiap perawat untuk memberikan pengobatan dan kenyamanan terhadap pasien. Tak jarang dalam menjalankan peran dan fungsinya ini seorang perawat akan dihadapkan pada kondisi yang menimbulkan konflik. Oleh karena itu seorang perawat harus memiliki kemampuan dalam mengelola setiap konflik yang muncul. Kemampuan menangani konflik yang terpenting adalah mengembangkan pengetahuan yang cukup dan sikap yang positif terhadap konflik,karena peran konflik yang tidak selalu negatif terhadap organisasi. Oleh karena itu, perawat harus mampu dalam mengambil keputusan yang benar dan tepat.
\end{abstract}

\section{Kata Kunci : Elemen Pengambilan Keputusan, Asuhan Keperawatan,Tindakan Keperawatan,Manajemen Keperawatan.}




\section{A. LATAR BELAKANG}

Pengambilan keputusan adalah bagian kunci kegiatan manajer. Kegiatan ini memegang peranan penting terutama bila manajer melaksanakan fungsi perencanaan. Dalam proses perencanaan, manajer memutuskan tujuan-tujuan organisasi yang akan dicapai, sumber daya yang akan digunakan, dan siapa yang akan melaksanakan tugas tersebut.

Penting bagi perawat untuk mampu mengambil keputusan klinis dengan melibatkan pasien dan keluarga dalam asuhan keperawatannya sehingga proses keperawatan yang diberikan kepada klien ini diarahkan sebagai proses refleksi baik bagi perawat ataupun klien. Keputusan klinis adalah suatu proses yang meliputi diagnosis klinis, penilaian dan keputusan tentang apa yang harus dilakukan oleh seorang perawat.Tujuannya adalah mengetahui cara pengambilan keputusan klinis keperawatan.

Proses pengambilan keputusan merupakan sebuah refleksi dari perawat ataupun klien, pengambilan keputusan klinis keperawatan harus ada interaksi antara perawat-klien, pengambilan keputusan klinis keperawatan dapat dilakukan dalam setiap proses keperawatan, tugas perawat pada saat proses pengambilan keputusan ini adalah sebagai fasilitator untuk memberikan fasilitas dan dukungan pada klien, pengambilan keputusan klinis dengan melibatkan klien akan meningkatkan tingkat kemandirian bagi klien, pengambilan keputusan klinis diperlukan kemampuan berfikir kritis bagi perawat. Yang terjadi di Indonesia pengambilan keputusan belum sepenuhnya dilakukan bersama antara perawat-klien. Perawat masih berperan sebagai pengambil keputusan tunggal. Sehingga dibutuhkan pemahaman lebih lanjut terkait dengan pengambilan keputusan klinis keperawatan dengan harapan peran perawat akan lebih terlihat nyata sebagai pemberi asuhan yang akan meningkatkan kepercayaan masyarakat terhadap profesi keperawatan.

Dalam pengambilan keputusan,ada beberapa elemen yang digunakan sebagai penentu pengambilan keputusan yakni antara lain Pengumpulan data,hipotesa,rencana kegiatan alternative,pemecahan masalah serta asumsi.

Namun,dalam makalah ini akan dibahas elemen salah satunya yakni elemen hipotesa yang tepat untuk pengambilan keputusan seorang perawat. 


\section{B. METODE}

Dalam karya ilmiah ini penulis menggunakan metode kepustakaan dengan cara membaca berbagai sumber seperti : buku,ebook,jurnal,karya ilmiah,dan sumber lainnya yang dapat dipercaya dikarenakan agar setiap pembaca tidak dipusingkan dengan artikelartikel yang kurang efektif dan belum dianalisis kebenarannya.Sumber-sumber yang dibaca dan dicari penulis juga berkenaan dengan materi permasalahan yang akan dibahas oleh penulis sehingga sistematis yang dibahas selalu berhubungan dan dapat mempermudah pemahaman pembaca.

\section{HASIL}

Hubungan perawat klien adalah dasar dari praktik keperawatan yang berfokus pada pasien (patient centered care). Keterlibatan pasien merupakan inti dari proses keperawatan, sehingga partisipasi pasien dalam proses keperawatan menjadi penting dalam penentuan kualitas dan efektifitas dalam pelayanan asuhan keperawatan. Membina hubungan ini didasarkan pada hubungan yang percaya, menghormati dan hubungan profesianal dengan mengedepankan nilai etik dan disiplin profesi.

Selama praktek, profesional keperawatan menghadapi sejumlah situasi yang berbeda melibatkan klien dan pemenuhannya yang berbeda pula. Proses pengambilan keputusan klinis merupakan komponen penting dalam proses keperawatan,sehingga dibutuhkan kemampuan perawatan karena Keterbatasan pengetahuan dan kemampuan yang dimiliki perawat dapat menghambat perawat dalam mengambil keputusan mengenai perawatan yang akan diberikan kepada klien yang akan berakibat fatal terhadap klien.

Penilaian dan keputusan klinis sangat dibutuhkan untuk mendapatkan kualitas pelayanan yang optimal.Keputusan klinis adalah suatu proses yang meliputi diagnosis klinis, penilaian dan keputusan tentang apa yang harus dilakukan.Proses pengambilan keputusan dalam praktik klinik keperawatan dipahami sebagai serangkaian keputusan yang dibuat oleh perawat dalam interaksinya dengan pasien mengenai jenis pengamatan yang akan dilakukan dalam situasi yang di alami klien (pengkajian keperawatan), perumusan diagnosa keperawatan, rencana tindakan keperawatan yang harus diambil, tindakan keperawatan yang akan diambil serta evaluasi. 
Perlu dipahami bahwa istilah keputusan klinis merupakan pilihan dianatara alternatif yang ada sebagai upaya pemecahan masalah.Berpikir kritis digambarkan sebagai "sebuah proses, tujuan untuk membuat keputusan yang masuk akal tentang apa yang harus percaya dan apa yang harus dilakukan". Pengambilan keputusan klinis adalah sebuah proses yang melibatkan kedua penalaran diagnostik dan penilaian klinis. Tindakan dalam ini tindakan diarahkan sebagai proses refleksi dari perawat maupun pasien.

Pengambilan keputusan sangat penting keberadaannya dalam asuhan maupun dalam manajemen keperawatan. Pengambilan keputusan merupakan suatu proses yang mencakup semua penilaian kegiatan yang diperlukan guna membuktikan dan meperlihatkan pilihan terbaik dalam menyelesaiakan suatu masalah tertentu. Setiap keputusan adalah akibat dari sebuah proses dinamis yang dipengaruhi oleh banyak kekuatan, pengambilan keputusana bukan merupakan prosedur yang tetap akan tetapi sebuah proses yang beruntun. Pengambilan keputusan adalah proses yang melibatkan pendekatan sistemik yang harus diadaptasikan dengan lingkungan.

\section{PEMBAHASAN}

Bagaimanan perawat dalam mengambil keputusan klinis? Pengambilan keputusan keperawatan dilakukan pada semua tahap proses keperawatan. Sehingga seorang perawat harus mampu berpikir ktitis, berkomunikasi dengan baik sebagai suatu elemen penting dalam pengaambilan keputusan klinis, sehingga terjadi pembelajaran berkelanjutan bagi pasien sehingga meningkatkan tingkat kemandirian pasien.

Pengambilan keputusan merupakan proses kognitif yang kompleks dan sering didefinisikan sebagai suatu upaya memutuskan serangkaian tindakan tertentu. Pengambilan keputusan sering dianggap sinonim dengan manajemen. Dari pengertian diatas dapat disimpulkan bahwa pengambilan keputusan adalah suatu proses berpikir dalam menentukan pilihan terbaik untuk menyelesaikan suatu masalah dengan langkah-langkah yang berurutan.

Manajemen keperawatan membutuhkan keputusan yang dibuat oleh perawat pada setiap tingkatan bagian dibangsal atau unit.Banyak waktu perawat dihabiskan untuk mengkaji isu, menyelesaikan masalah, dan membuat keputusan secara kritis. 
Kualitas keputusan yang dibuat oleh pemimpin atau manajer merupakan faktor yang sangat berpengaruh dalam keberhasilan atau kegagalan mereka.Marquis \& Huston menyebutkan untuk meningkatkan kemampuan pengambilan keputusan, perlu digunakan model proses yang adekuat sebagai dasar teori untuk memahami dan mengaplikasikan keterampilan berpikir kritis. Ada lima langkah sebagai elemen kritis dalam penyelesaian masalah dan pengambilan keputusan, yaitu:

\section{1) Penetapan tujuan}

Penetapan tujuan harus jelas dan konsisten dengan pernyataan filosofi individu atau organisasi. Jika aspek tersebut tidak terpenuhi, maka kemungkinan keputusan yang dibuat berkualitas buruk. Handoko mengemukakan hal pertama yang harus dilakukan seorang manajer adalah menemukan dan memahami masalah untuk diselesaikan agar perumusan masalah menjadi jelas.

\section{2) Mengumpulkan data secara cermat}

Setelah perawat menentukan atau merumuskan masalah dan tujuan, perawat harus menentukan data-data yang dibutuhkan untuk membuat keputusan yang tepat. Pengumpulan data dimulai dengan mengidentifikasi masalah atau kesempatan untuk mengambil keputusan dan berlanjut ke proses penyelesaian masalah. Ketika mengumpulkan informasi, manajer harus berhati-hati agar data yang dimilikinya dan orang lain tidak salah fakta.

\section{3) Membuat banyak alternatif}

Semakin banyak alternatif yang dapat dibuat dalam penyelesaian masalah dan pengambilan keputusan, semakin besar kesempatan menghasilkan keputusan akhir. Dengan tidak membatasi hanya pada satu alternatif yang jelas, orang akan mampu untuk menerobos pola kebiasaan atau pengekangan berpikir dan memungkinkan munculnya gagasan baru. Menurut Handoko setelah membuat alternatif keputusan, perawat harus mengevaluasi alternatif tersebut untuk menilai keefektifitasannya, dan langkah selanjutnya adalah memilih alternatis terbaik yang akan digunakan dalam pengambilan keputusan. 


\section{4) Berpikir logis}

Selama proses penyelesaian masalah, seseorang harus menarik inferensi (simpulan) informasi dan mempertimbangakan informasi serta alternatif secara cermat. Kesalahan berlogika pada titik ini akan mengarahkan pada kualitas keputusan yang buruk. Ada beberapa cara berpikir yang tidak logis, seperti: terlalu menggeneralisasi, afirmasi konsekuensi, dan berargumen dengan analogi.

\section{5) Memilih dan bertindak secara efektif}

Mengumpulkan informasi yang adekuat, berpikir logis, memilih diantara banyak alternatif, dan memahami pengaruh nilai-nilai individu tidaklah cukup. Dalam analisis akhir, seseorang harus bertindak. Banyak orang yang menunda untuk bertindak karena mereka kurang berani untuk menghadapi konsekuensi pilihan yang mereka ambil.Pada tahap ini perawat perlu memperhatikan berbagai resiko dan ketidakpastian sebagai konsekuensi keputusan yang telah dibuat, karena dengan mengambil langkah tersebut manajer dapat menentukan kegiatan-kegiatan yang diperlukan untuk menanggulangi hambatan dan tantangan yang akan terjadi.

Pengambilan keputusan klinis merupakan bagian dari kobarorasi klien dan pemberi pelayanan kesehatan dalam hal ini adalah perawat. Sehingga seorang perawat dituntut mampu untuk melakukan pengambilan keputusan dengan melibatkan klien, perawat bukan pengambil keputusan tunggal akan tetapi sebagai fasilitator bagi klien. Ketepatan pengambilan keputusan akan di pengaruhi oleh kompentisi perawat, kemampuan berkomunikasi, lingkungan serta budaya. Penting bagi perawat untuk selalu meningkatkan kapasitas dirinya dalam pemberian asuhan keperawatan hal ini akan meningkatkan kepercayaan masyarakat terhadap perawat yang selanjutnya akan meningkatkan profesionalisme perawat. Hal ini bisa digunakan sebagai acuan dalam melakukan hubungan interdisiplin. Pengambilan keputusan yang tepat akan meningkatkan kemandian klien dalam asuhannya serta membantu klien untu menentukan pilihan bantuan yang tepat sesuai dengan kondisinya. Klien yang mandiri akan menurunkan beban kerja perawat sehingga pelayanan keperawatan akan lebih efektif dan efisien dalam penggunaan sumber daya. 


\section{Model Pengambilan Keputusan}

Dalam mengambil keputusan juga terdapat model yang digunakan dalam mengambil keputusan yakni :

\section{Model Normatif}

Menurut Swanburg, model normatif untuk pembuatan keput usan ini tidak realistis karena asumsinya jelas memilih diantara alternative yang teridentifikasi. Ada tujuh langkah untuk membuat keputusan dalam model analisis ini: a) menemukan dan menganalisis masalah, b) mengidentifikasi semua alternatif yang memungkinkan, c) mengevaluasi pro dan kontra dari masing-masing alternatif, d) mengurutkan alternatif, e) memilih alternative yang dapat memaksimalkan kepuasaan, f) pelaksanaan, g) evaluasi.

2. Model Pohon Keputusan

Menurut Vroom menggunakan jawaban untuk tujuh pertanyaan diagnostik dalam bentuk pohon keputusan untuk mengidentifikasi tipe-tipe gaya kepemimpinan yang digunakan dalam model manajemen pembuatan keputusan.

\section{Model Deskriptif}

Menurut Simon mengembangkan model ini didasarkan pada asumsi bahwa pembuat keputusan adalah seseorang yang melihat masalah secara rasional dalam membuat solusi yang bisa dilakukan yang didasarkan pada informasi yang diketahuinya.

\section{E. PENUTUP}

Proses pengambilan keputusan klinis merupakan komponen penting dalam proses keperawatan,sehingga dibutuhkan kemampuan perawatan karena Keterbatasan pengetahuan dan kemampuan yang dimiliki perawat dapat menghambat perawat dalam mengambil keputusan mengenai perawatan yang akan diberikan kepada klien yang akan berakibat fatal terhadap klien.Ada beberapa langkah sebagai elemen pengambilan keputusan yakni pengumpulan data,hipotesa,rencana kegiatan,alternative,pemecahan masalah dan asumsi. Pengambilan keputusan yang tepat akan meningkatkan kemandian klien dalam asuhannya serta membantu klien untu menentukan pilihan bantuan (asuhan keperawatan) yang tepat sesuai dengan kondisinya. 


\section{F. DAFTAR PUSTAKA}

ANGGRIYANI, DINNY.(2017).Analisis Perbedaan Sikap Anggota Keluarga Dan Perawat Terhadap Pendampingan Keluarga Saat Dilakukan Tindakan Invasif Di Igd Dan Icu Puskesmas Ketapang Probolinggo. Undergraduate (S1) thesis, University of Muhammadiyah Malang.

Candra Dewi Rahayu, et.al. (2020). PENGAMBILAN KEPUTUSAN KLINIS PERAWAT. Jurnal Ilmiah Kesehatan,9(2), 1-11.

Desi Eka Sukmawati, 124010197 (2016) Pengaruh Penilaian Kinerja Dan Motivasi Kerja Terhadap Kepuasan Kerja Karyawan Di Instalasi Rawat Jalan Rumah Sakit Umum Daerah Al Ihsan Di Kabupaten Bandung. Skripsi(S1) thesis, Fakultas Ekonomi Unpas Bandung.

ENDANG TRIHASTUTI, 131411123008 (2016) Pengaruh Kepemimpinan, Motivasi Dan Beban Kerja Terhadap Kinerja Perawat Dalam Pendokumentasian Asuhan Keperawatan Di Ruang Rawat Inap Penyakit Dalam Rumah Sakit X Surabaya. Skripsi thesis, UNIVERSITAS AIRLANGGA.

Gunawan. (2016). FAKTOR-FAKTOR YANG MEMENGARUHI PENERIMAAN PERAWAT MELAKSANAKAN PENDOKUMENTASIAN ASUHAN KEPERAWATAN BERBASIS KOMPUTER . Jurnal Pendidikan,1(10), 1926-1934 .

Julianto, M. (2016). Peran dan Fungsi Manajemen Keperawatan dalam Manajemen Konflik . Fatmawati Hospital Journal,8(2) 1-10.

Mariana, D. (2019). HUBUNGAN KUALITAS PELAYANAN KEPERAWATAN RAWAT INAP DENGAN PROSES PENGAMBILAN KEPUTUSAN PASIEN UNTUK MEMILIH RUMAH SAKIT. Jurnal Ilmiah Multi Science Kesehatan,10(2), 145-162.

Mugianty,Sri,et.al.(2016).Manajemen dan kepemimpinan dalam praktek keperawatan. Jakarta :Pusdik SDM Kesehatan.

Simamora, R. H. (2005). Hubungan Persepsi Perawat Pelaksana Terhadap Penerapan Fungsi Pengorganisasian Yang Dilakukan Oleh Kepala Ruangan Dengan Kinerjanya Diruang Rawat Inap RSUD Koja Jakarta Utara (Doctoral dissertation, Tesis FIK UI, Tidak dipublikasikan).

Simamora, R. H. (2019). Menjadi perawat yang: CIH'HUY. Surakarta: Kekata Publisher. 
Yusnaini, Yusnaini (2016) Analisis Kemampuan Kepemimpinan Klinis Perawat Pelaksana Berdasarkan Pendekatan Clinical Leadership Competency Framework dan Faktor-Faktor Determinannya di Ruang Rawat Inap RSUD Padangsidimpuan. Masters thesis, Universitas Andalas.

Yusuf,AH,et.al.(2017). Riset Kualitatif Dalam Keperawatan.Jakarta : Mitra Wacana Media. 